\title{
Foreign Currency Mortgages Recast as Options on Commodity Futures
}

\author{
Rebecca Abraham, Joel Auerbach \\ Huizenga College of Business and Entrepreneurship, Nova Southeastern University, Fort Lauderdale, USA \\ Email: abraham@nova.edu, jaueruk@gmail.com
}

How to cite this paper: Abraham, R. and Auerbach, J. (2019) Foreign Currency Mortgages Recast as Options on Commodity Futures. Theoretical Economics Letters, 9, 2291-2313.

https://doi.org/10.4236/tel.2019.97145

Received: July 12, 2019

Accepted: September 22, 2019

Published: September 25, 2019

Copyright ( 2019 by author(s) and Scientific Research Publishing Inc. This work is licensed under the Creative Commons Attribution International License (CC BY 4.0).

http://creativecommons.org/licenses/by/4.0/

(c) (i) Open Access

\begin{abstract}
A foreign currency mortgage is debt for the purchase of residential property denominated in foreign currency. The borrower makes monthly payments in foreign currency. Devaluation of the domestic currency results in higher monthly payments. Practitioners have proposed solutions to avoid mortgage default. However, many of the practitioner solutions place excessive financial burdens on foreign lenders, while relieving domestic borrowers of responsibility. The goal of this paper is to present a solution that shares responsibility equitably between borrowers and lenders. First, we evaluate practitioner solutions by placing them in theoretical models. Then, the paper presents a solution, in which mortgages (loans) are viewed as derivatives (not loans). This is innovative, in that it takes mortgages out of banking and places them within investments. We recognize that investors have differential attitudes to risk. Accordingly, the proposed solution is presented in two contexts, i.e. from the perspective of a risk averse investor who shuns risk, or a risk taker, who is willing to take excessive risk to pursue returns. In the proposed solution, a call buyer may exercise the option, purchasing a futures contract to obtain the currency at a strike price that is less than the spot exchange rate. During the lengthy, uncertain delivery period, the exchange rate may vary more than the immediate period defined by the spot rate, in the form of jump diffusion models with stochastic volatility. The call buyer may purchase foreign currency at a strike price equal to the forward rates of a series of 1-period futures contracts with total life equal to the life of the mortgage. As strike prices continue to increase, with domestic currency depreciation, a repayment vehicle in the form of a portfolio of high-yielding securities is proposed, to produce the funds needed to meet forthcoming increases in monthly payments.
\end{abstract}

\section{Keywords}

Aberrancy, Gamma, Wronskian Relations, Jump Diffusion, Currency Mortgage 


\section{Introduction}

Beginning in 2007-2008, residents of countries in Central and Eastern Europe acquired mortgages in the Swiss Franc at lower interest rates than the interest rates offered by their home country banks. Such foreign currency mortgages subsequently proved to be excessively risky in that the depreciation of domestic exchange rates increased monthly payments by about $10 \%$ in three months. Up to $33 \%$ of the mortgages in Croatia, $54 \%$ in Hungary, and $10 \%$ in Romania were foreign currency mortgages in 2016-2017 [1]. Such mortgages were not confined to Eastern Europe. [2] reported that 20\% of the total value of mortgages made in Austria was made in Swiss francs. The interest rate benefit of borrowing in foreign currency was eliminated as the exchange rate between the Swiss franc and domestic currencies depreciated to increase monthly payments. Swiss interest rates remained lower due to the economy's greater macroeconomic stability, strengthening the exchange rate. [3] stated the following Uncovered Interest Parity Equation (1),

$$
\left(1+i_{s}\right)=E_{t}\left(S_{t+k}\right) / S_{t}\left(1+i_{c}\right)
$$

where,

$E_{t}\left(S_{t+k}\right)=$ expected future spot rate at time $t+k$,

$k=$ number of future periods, from time $t$,

$S_{t}=$ spot exchange rate at time $t$,

$I_{s}=$ interest rate in the foreign country, i.e. Switzerland,

$I_{c}=$ domestic interest rate, i.e. Croatia, Hungary, Romania, or Austria.

[4] termed uncovered interest parity as exchange rate overshooting, with an increase in the domestic price level leading to policy action to increase interest rates so that the interest rate benefit of the foreign currency mortgage is exactly offset by expectations of appreciation in the domestic exchange rate. Only part of the overshooting hypothesis may occur with foreign currency mortgages. We will show that, while initial overshooting of the exchange rate occurs, depreciation ensues, becoming the norm in successive time periods.

This paper fulfills four objectives. We present a solution to defaults from rising mortgage payments by removing foreign currency mortgages from bank lending to earning investment returns. We view a foreign currency mortgage as an investment in a call option on currency futures. A borrower purchases foreign currency each month to meet the mortgage payment. If the purchase price of the currency is affordable, he or she will exercise the option, and purchase the futures contract that permits purchase of the foreign currency at the low strike price, both at present (spot price), or in the future (futures price) upon delivery of the foreign currency. The spot rate is subject to a jump-process distribution of spot exchange rates that vary due to daily changes in exchange rates in a cost-of-carry model proposed in the literature [5]. [6] observed spot rate jumps in the yen-dollar exchange rate were quickly reversed during the same day. The futures price of the foreign currency will vary from the end of the current period to the end of the delivery period in a different jump-process model from the spot 
distribution to account for the greater fluctuation of exchange rates during a longer period. Borrowers may invest in high-yielding commodity portfolios to meet sharply increasing monthly mortgage payments. Secondly, this paper evaluates prevailing solutions that have been proposed. We show that our proposed solution is more just, as existing solutions place an excessive financial burden on lenders, while we set forth that responsibility should be shared by lenders and borrowers. Thirdly, we recognize that uncovered interest parity results from the impact of macroeconomic variables on exchange rates, so that models of solutions must include such variables. Finally, we relax the assumption of isoelastic utility of homogeneity in investor attitudes to risk. This paper creates optimal pricing models of foreign currency distributions for risk-averse borrowers, and risk-taker borrowers.

The remainder of this paper is organized as follows: Section 2 is a Review of Literature with a description of Macroeconomic Determinants of Exchange Rates, Background of Foreign Currency Mortgages and Underlying Theories, and the Distribution of Options on Currency Futures, Section 3 is an Examination of Existing Solutions to Stabilizing Mortgage Payments in Foreign Currency, Section 4 is the Proposed Solution along with an Alternative Solution, while Section 5 describes Conclusions.

\section{Review of Literature}

\subsection{Macroeconomic Determinants of Exchange Rates}

Inflation Rates, Interest Rates, and Government Debt. The relative Purchasing Power Parity Theory (PPP) maintains that countries with higher relative inflation rates experience currency depreciation. [7] set forth that the real exchange rate was defined as the nominal rate deflated by domestic and foreign price levels. Equation (2) presents $P P P$ as,

$$
e=s+p^{*}-p=\ln \left(s p^{*} / p\right)
$$

$e=\log$ of the real exchange rate,

$s=\log$ of domestic spot exchange rate per foreign currency unit,

$p, p^{*}=\log$ of domestic and foreign price levels,

or,

$$
e^{-}=k_{0} /\left(1-k_{t}\right)
$$

$e^{-}=$historical exchange rate, which follows a first-order autoregressive process,

$k_{0}=$ spot interest rate,

$k_{t}=$ discounted historical interest rate.

Long-run $P P P$ is violated, when the constant, $k_{t} \geq 1, e=e^{-}$is a requirement for Short-run $P P P$. Co-integration tests and unit root tests have shown some support for $P P P . P P P$ is supported when the real exchange rate is stationary, which occurs when the change in price level between two countries is equal to the change in the exchange rate, or when a unit root is not found in tests of statio- 
narity. [8] presents a series of cointegration tests [9] [10] [11] [12] with mostly weak support for $P P P$, and unit root tests [13] [14], and [15] with both strong and weak evidence supporting $P P P$. The tests employ a variety of methodologies, including the Stock-Watson Dynamic OLS Johansen Cointegration [9], and Johansen Cointegration [10] [11], Ng and Perron Unit Root Tests [13], ADF Unit Root Tests [14], and nonlinear panel root tests [15]. In all studies, contemporary data from the mid 1990s-mid 2000s was used.

In a country with high government debt, local investors may sell their government bonds, purchasing foreign investments, thereby depreciating the domestic currency. [16] empirically proved that government debt was a determinant of the declining value of the Polish Zloty. Fiscal deficits led to increased volatility of exchange rates, as observed in a study of 85 developing and transition economies [17].

Terms of Trade. The Harrod-Balassa-Samuelson model ([18]) posits that the rise in productivity of manufactured exports leads to higher wages. To compete for labor, businesses producing nontradable goods raise wages. The rise in prices of both exports and nontradables results in an increase in currency values, ceteris paribus. [19] empirically justified this model for the United Kingdom, Austria, Switzerland, Denmark, and Italy from 1999-2007. [20] attribute the appreciation of the yen to the dollar largely to Japan's trade surplus with the United States. [21] observed that an unfavorable external trade balance and decline in foreign reserves depleted the current account to the point of continuously declining currency values, for a Romanian sample from 2007-2011.

\subsection{Foreign Currency Mortgages: Background and Theory}

Background. Foreign currency mortgages became popular in Eastern and Central European countries, including Croatia, Hungary, Poland, and Romania, with up to $60 \%$ of mortgages denominated in foreign currency in 2016-2017 [1]. Homeowners in these countries viewed mortgages in Euros and Swiss francs as preferable to the higher interest rate mortgages in their own countries. [22] found that interest rate differentials were the primary determinant of private sector loans in Swiss francs in the new EU member states and Croatia. Further, low inflation, low inflation volatility, and the ability to predict future real interest rates of the Swiss economy made Swiss franc loans more appealing [23]. The unintended consequence of interest rate differentials is that the domestic currency depreciates. [24] created a repayment schedule for Eastern European foreign currency mortgages, showing currency depreciation of 25\% in Year 0, 25\% in year 2, to another $25 \%$ also in year 2 . Monthly payments rose $56 \%$ in year 2 . To a lesser extent, $4 \%$ of Austrian mortgage holders purchased Swiss franc loans. Easier repayment terms, such as mortgages with a lower loan-to-value ratio, combined with high-yielding investments providing a stream of cash flows to pay monthly payments, were provided by Swiss banks [25].

Uncovered Interest Parity. The uncovered interest rate parity theory is based 
on the relationship between inflation rates, interest rates, and exchange rates. If the domestic economy has higher inflation than the foreign economy, policy makers in the domestic economy will increase interest rates with the desire to attract foreign capital. The resulting domestic interest rate will be substantially higher than the foreign interest rate, as shown in Equation (2) [26], In other words, the inflation or higher domestic price differential, $\left(p_{t}-p_{t}^{*}\right)$, results in a higher interest rate differential, $\left(i_{t}-i_{t}^{*}\right)$.

$$
\left(p_{t}-p_{t}^{*}\right)=\left(m_{t}-m_{t}^{*}\right)-\phi\left(y_{t}-y_{t}^{*}\right)+\eta\left(i_{t}-i_{t}^{*}\right)
$$

where,

$$
\begin{aligned}
& p_{t}=\text { price index at time } t \text {, domestic country, } \\
& p_{t}^{*}=\text { price index at time } t \text {, foreign country, } \\
& m_{t}=\text { money supply at time } t \text {, domestic country, } \\
& m_{t}^{*}=\text { money supply at time } t \text {, foreign country, } \\
& y_{t}=\text { output at time } t \text {, domestic country, } \\
& y_{t}^{*}=\text { output at time } t \text {, foreign country, } \\
& i_{t}=\text { interest rate at time } t \text {, domestic country, } \\
& i_{t}^{*}=\text { interest rate at time } t \text {, foreign country. }
\end{aligned}
$$

According to Equation (4), the ratio of the foreign interest rate to the domestic interest rate $=$ ratio of the final exchange rate to the current spot exchange rate. In response to the higher domestic interest rates and inflation rates, more of the domestic currency will have to be exchanged for each unit of foreign currency. The domestic currency will be devalued with respect to the foreign currency, or, the future spot exchange rate will have a lower value than the current spot exchange rate.

$$
\left(1+i_{t}^{*}\right)=E_{t}\left(S_{t+k}\right) / S_{t}\left(1+i_{t}\right)
$$

where,

$$
\begin{aligned}
& E_{t}\left(S_{t+k}\right)=\text { expected future spot rate at time } t+k \\
& k=\text { number of future periods, from time } t \\
& S_{t}=\text { spot exchange rate at time } t \\
& i_{t}=\text { interest rate in the foreign country, i.e. Switzerland, } \\
& i_{t}^{*}=\text { domestic interest rate, i.e. Croatia, Hungary, Romania, or Austria. }
\end{aligned}
$$

Empirical support for short-term uncovered interest rate parity was provided over an intraday period by [27] who found that interest rate differentials led to investors being compensated for the risk of depreciation for currency pairs in the European Monetary System, and [28] who observed interest rate differentials causing exchange rate depreciation on dollar exchange rates with the yen, Swiss franc, and pound over a fifteen-year period.

The Overshooting Hypothesis. During a monetary expansion, the increase in the money supply is initially matched by an increase in the prices of goods. Governments curb this inflation by increasing interest rates, which causes the short-term interest rate to overshoot its equilibrium level. Higher domestic prices diminish the value of domestic assets. The domestic currency becomes unattractive as a source of investment, leading to capital outflows, followed by deprecia- 
tion of the exchange rate [4]. This sequence of outcomes is realized in the Eastern and Central European countries that borrow using foreign currency mortgages. The next phase of the overshooting hypothesis, is that as interest rates increase, domestic investors will anticipate an appreciation of the exchange rate. [29] provided empirical support for the overshooting hypothesis for 4 open economies, whose exchange rates first depreciated, and then appreciated 1 - 2 quarters after a monetary policy shock.

While the initial depreciation of exchange rates occurs in Eastern and Central European economies, currency appreciation does not occur against currencies such as the Swiss franc. As these Eastern European economies lack macroeconomic stability, failing to attract the capital inflows that permit an offsetting increase in exchange rates there is unlikely to be appreciation of their currencies. As the domestic currency continues to depreciate, more domestic currency must be exchanged to meet monthly mortgage payments, or borrowers of foreign currency mortgages continue to face higher mortgage payments. In the event that they reach a payment level that is unaffordable, widespread defaults result.

\subsection{Research on the Distributions of Options on Commodity Futures}

Call options on commodities permit purchases of commodities, including pork, soybeans and wheat, or natural resources, including oil. Spot prices on commodities are sensitive to short-term conditions, including, the weather, transportation, storage, or demand of commodity traders in the derivatives markets. Futures prices of commodities, during the delivery period, are relatively unchangeable, as delivery periods are short for agricultural commodities due to spoilage, and for oil due to price-setting by OPEC, respectively. Accordingly, the [30] model values commodities in terms of their spot prices, considering the futures prices to be equivalent to a riskless bond with constant risk-free interest. Likewise, [31] assumed that futures prices would be equivalent to a zero-coupon bond, with minimal risk. [32] added variability to spot prices, with jumps in current commodity prices, to model changes in daily commodity prices due to weather or storage, and unchanged futures prices. We challenge the assumption of constant interest rates for futures prices, given that uncertainties in macroeconomic variables will alter interest rates during the delivery period in support of certain commodity models, that recognize price fluctuations in both spot and futures prices, as representing volatility that may vary over time, and must be included in valuation. Such volatility may be time-varying [33] [34], or static [35]. This paper concurs with the inclusion of volatility with large currency fluctuations represented by jump process models. This paper sets forth that a jump diffusion model is more appropriate, both to describe current spot price distributions, and futures price distributions during the long delivery period, given that currency prices depend upon macroeconomic variables, which experience both short-term and long-term fluctuations [33]. However, the [33] model does not make provision for macroeconomic variables. 


\section{Existing Solutions to Stabilizing Mortgage Payments in Foreign Currency Mortgages}

Limiting Increases in Foreign Currency Payouts. We show that the foreign lender will experience significant losses from the following strategy of the borrower limiting increases in foreign currency payments. The mortgage repayment schedule may be described as,

$$
D_{f}=D P_{f}+P M T_{1} /\left(1+s_{1}\right)+P M T_{2} /\left(1+s_{2}\right)^{2}+P M T_{3} /\left(1+s_{3}\right)^{3} P M T_{n} /\left(1+s_{n}\right)^{n}(6)
$$

where,

$D_{f}=$ Foreign Currency Debt,

$D P_{f}=$ Down Payment in Foreign Currency,

$P M T_{1}, P M T_{2}, P M T_{3} \ldots . P M T_{n}=$ Monthly Mortgage Payments Paid in Months $1,2,3 \ldots . n$

$s_{1}, s_{2}, s_{3}, \ldots \ldots . s_{n}=$ foreign interest rate in months $1,2,3, \ldots . n$.

Rearranging Equation (4),

$$
D_{f}-D P_{f}=P M T_{1} /\left(1+s_{1}\right)+P M T_{2} /\left(1+s_{2}\right)^{2}+. . P M T_{n} /\left(1+s_{n}\right)^{n}
$$

If $e x$ is the exchange rate and $D C$ is the domestic currency, as the domestic currency gets devalued over time, larger amounts of domestic currency will have to be exchanged for the foreign currency, or

As the last payment on the mortgage may be 15 years into the future, and since mortgage payments are increasing monthly, the final payment may be exponentially higher than the initial payment.

Therefore, Equation (6) may be rewritten as,

$$
D_{f}-D P_{f}=D C_{1} e x_{1} /\left(1+s_{1}\right)+D C_{2} e x_{2} /\left(1+s_{2}\right) D C_{n} e x_{n} /\left(1+s_{n}\right)
$$

Normally, depreciation of the domestic exchange rate, will result in an increase in monthly mortgage payments in foreign currency. However, the central bank will not permit this increase to occur, leading to possible default as borrowers underpay. $D C^{*} e x$ at the higher foreign currency conversion rate expressed in Equation (8) will fail to occur, leading to losses to the lender. The source of the devaluation of the domestic currency is the differential inflation rate, leading to differential real interest rates, leading to differential nominal interest rates, and finally, devaluation of the exchange rate. The impact of differential real interest rates, $x$, and differential inflation rates $y$, on differential nominal interest rates about a point, $(a, b)$, is expressed as a Taylor series expansion,

$$
\begin{aligned}
& f(a, b)+(x-a) f_{x}(a, b)+(y-b) f_{y}(a, b)+1 / 2 !\left((x-a)^{2} f_{x x}(a, b)\right. \\
& +2(x-a)(y-b)+2(x-a)(y-b) f_{x y}(a, b)+(y-b)^{2} f_{y y}
\end{aligned}
$$

The change in exchange rate is the first derivative of Equation (9), as follows,

$$
\begin{aligned}
& f^{\prime}(a, b)+(x-a) f_{x}^{\prime}(a, b)+(y-b) f_{y}^{\prime}(a, b)+(x-a) f_{x x}^{\prime}(a, b) \\
& +2(x-a)(y-b)+2(x-a)(y-b) f_{x y}^{\prime}(a, b)+2(y-b) f_{y y}^{\prime}
\end{aligned}
$$




$$
\begin{aligned}
& f^{\prime}(a, b)+(x-a) f_{x}^{\prime}(a, b)+(y-b) f_{y}^{\prime}(a, b)+(x-a) f_{x x}^{\prime}(a, b) \\
& +2(x-a)(y-b)+2(x-a)(y-b) f_{x y}^{\prime}(a, b)+2(y-b) f_{y y}^{\prime} \neq \text { DCex }
\end{aligned}
$$

At the upper bound, the second derivative of the left side of Equation (9), must have the maximum mortgage payment, $D C_{n} e x_{n}$. Yet, this mortgage payment is constrained to remain at $D C_{1}$, resulting in significant losses to the foreign lender,

$$
\begin{aligned}
& f^{\prime \prime}(a, b)+(x-a) f_{x} "(a, b)+(y-b) f_{y} "(a, b)+(x-a) f_{x x} "(a, b) \\
& +2(1-a)(1-b)+2(x-a)(y-b) f_{x y}^{\prime \prime}(a, b)+2(y-b) f^{\prime \prime \prime}{ }_{y y} \\
& =D C_{1} /\left(1+s_{1}\right)+D C_{1} /\left(1+s_{2}\right) . . D C_{1} /\left(1+s_{n}\right)
\end{aligned}
$$

Cap the domestic interest rate. Certain central banks cap the domestic nominal interest rate. Borrowers will rush to convert domestic currency at the low exchange rate. The supply of foreign currency will be quickly exhausted, so that lenders will receive smaller monthly mortgage payments, after the first few months. Foreign lenders will lose, as their monthly mortgage income decreases, while borrowers will gain, as their payments decrease. We derive an equilibrium between the supply and demand for foreign currency, which is violated by capping the domestic interest rate. The equilibrium in Equation (14) of parity between the value of the domestic currency and the value of the foreign currency is violated.

At the equilibrium exchange rate,

The supply of foreign currency = supply of domestic currency to purchase foreign currency,

Given the following notation,

$x_{t f}=$ trade balance, foreign country,

$x_{g f}=$ government deficit, foreign country,

$x_{i f}=$ inflation, foreign country,

$x_{t d}=$ trade balance, domestic country,

$x_{g d}=$ government deficit, domestic country,

$X_{i d}=$ inflation, domestic country.

To examine if Equation (12) is upheld, we represent each of the variables in Equation (12) as a Legendre function [34]. The left side is,

$$
\begin{aligned}
& {\left[1 / \Pi \int x_{t f} \sqrt{ } x_{t f}^{2}-1(2 t-1)^{s} d t / \sqrt{ } t(1-t)\right]_{-} f+\left[1 / \Pi \int x_{g f} \sqrt{ } x_{g f}^{2}-1(2 t-1)^{s} s\right.} \\
& d t / \sqrt{ } t(1-t)]_{-} f+\left[1 / \Pi \int x_{i f}+\sqrt{ } x_{i f}^{2}-1(2 t-1)^{s} d t / \sqrt{ } t(1-t)\right]_{-} f
\end{aligned}
$$

The right side is,

$$
\begin{aligned}
& {\left[1 / \Pi \int_{x_{-t d}} \sqrt{ } x_{q d}^{2}-1(2 t-1)^{s} d t / \sqrt{ } t(1-t)\right]_{-} d+\left[1 / \Pi \int x_{g d} \sqrt{ } x_{g d}^{2}-1(2 t-1)^{s} s\right.} \\
& d t / \sqrt{ } t(1-t)]_{-} d+\left[1 / \Pi \int x_{i d}+\sqrt{ } x_{i d}^{2}-1(2 t-1)^{s} d t / \sqrt{ } t(1-t)\right]_{-} d
\end{aligned}
$$

Subtracting the right side from the left side yields,

$$
\begin{aligned}
& {\left[1 / \Pi \int\left(x_{t f}-x_{t d}\right)+\sqrt{ }\left(x_{t f}^{2}-x_{t d}^{2}\right)-1(2 t-1)^{s} d t / \sqrt{ } t(1-t)\right.} \\
& +1 / \Pi \int\left(x_{g f}-x_{g d}\right)+\sqrt{ }\left(x_{g f}^{2}-x_{g d}^{2}\right)-1(2 t-1)^{s} d t / \sqrt{ } t(1-t) \\
& +1 / \Pi \int\left(x_{i f}-x_{i d}\right)+\sqrt{ }\left(x_{i f}^{2}-x_{i d}^{2}\right)-1(2 t-1)^{s} d t / \sqrt{ } t(1-t)
\end{aligned}
$$


Differentiating with respect to trade $t$, government debt, $g$, and inflation, $i$, and dividing throughout by $c V_{d}$

$$
3 / \Pi c v_{d}(2 t-1)^{s} d t / \sqrt{ } t(t-1)+1=e x
$$

Convert to a Domestic Currency Mortgage. Central banks may forego the need for borrowers to purchase foreign currency altogether, by converting the foreign currency mortgage to a domestic mortgage. The foreign lender will lose the mortgage payments entirely.

The domestic bank pays the foreign lender for the foreign currency loan. The payment, $B$, includes the present value of all future mortgage payments that the foreign lender will no longer receive. We model these foregone payments as a Laplace distribution in Equation (14). A Laplace distribution is an S-shaped double-exponential distribution that could approximate exponentially rising future exchange rates [35]. To account for additional discontinuities due to exchange rate jumps, we add the first moment of the Laplace distribution in Equation (15),

$$
\begin{aligned}
& B=0.5+0.5 \operatorname{sgn}(x-\mu)(1-\exp (-\mid x-\mu) ! / b)) \\
& +0.5 \sum k=0 \text { to } r\left[r ! /(r-k) ! b^{k} \mu^{r-k}\left\{1+(-1)^{k}\right\}\right]
\end{aligned}
$$

where,

$B=$ Purchase Price of Foreign Currency Mortgage, $(x-\mu)=$ Foreign Currency Monthly Payment, $\mu=$ Scale Parameter of the Laplace Distribution.

The emerging market bank writes a new domestic currency mortgage, for which it demands $(B+$ Spread $)$, to be paid by domestic currency borrowers. An additional moment of the Laplace distribution may be added in Equation (16) to account for discontinuities in the Spread over the life of the mortgage,

$$
\begin{aligned}
& B+\text { Spread }=0.5+0.5 \operatorname{sgn}(x-\mu)(1-\exp (-\mid x-\mu) ! / b)) \\
& +0.5 \sum k=0 \text { to } r\left[r ! /(r-k) ! b^{k} \mu^{r-k}\left\{1+(-1)^{k}\right\}\right] \\
& + \text { Spread }\left[0.5 \sum k=0 \text { to } r\left[r ! /(r-k) ! b^{k} \mu^{\wedge} r-k\left\{1+(-1)^{k}\right\}\right]\right.
\end{aligned}
$$

Equation (16) is equivalent to the new domestic currency mortgage in Equation (17), whose monthly payment $=(D C(1+r))$, where $r$, the prevailing interest rate, is an increasing function of the market interest rate for an adjustable-rate mortgage.

$$
\begin{aligned}
& B+\text { Spread }=D C_{1}\left(1+r_{1}\right) /\left(1+d_{1}\right)+D C_{2}\left(1+r_{2}\right) /\left(1+d_{2}\right)^{2} .+ \\
& \ldots D C_{n}\left(1+r_{n}\right) /\left(1+d_{n}\right)^{n}
\end{aligned}
$$

Equating the right side of Equation (15) and Equation (16) yields the stream of payments for the domestic mortgage, which, with the spread, is higher than the foreign currency mortgage.

$$
\begin{aligned}
& 0.5+0.5 \operatorname{sgn}(x-\mu)(1-\exp (-\mid x-\mu) ! / b))+0.5 \sum k=0 \text { tor }\left[r ! /(r-k) ! b^{k}\right. \\
& \left.\mu^{r-k}\left\{1+(-1)^{k}\right\}\right]+\operatorname{Spread}\left[0.5 \sum k=0 \text { tor }\left[r ! /(r-k) ! b^{k} \mu^{\wedge} r-k\left\{1+(-1)^{k}\right\}\right]\right. \\
& =D C_{1}\left(1+r_{1}\right) /\left(1+d_{1}\right)+D C_{2}\left(1+r_{2}\right) /\left(1+d_{2}\right)^{2} .+\ldots D C_{n}\left(1+r_{n}\right) /\left(1+d_{n}\right)^{n}
\end{aligned}
$$

Pegging the exchange rate. A pegged exchange rate occurs when an emerg- 
ing market fixes the value of its currency to the value of foreign currency. Pegging the exchange rate between the stronger lending currency, and weaker borrowing currency results in an unstable stream of mortgage payments, which ends upon collapse of the peg. This occurred with the Euro-Swiss Franc (henceforth, $E U R / C H F$ ) peg, which had a brief, turbulent life from 2010-2015 [36]. The EUR/CHF exchange rate was 1.2 in September 2010. Within an IS-LM (investment savings-liquidity preference money supply framework) [37]. The value of Swiss currency supplied to meet cash needs to that demanded for investment and savings was established at 1.2 EUR/1 CHF as the equilibrium price between the two currencies. The $I S$ curve may be presented as,

$$
Y=C(Y-T(Y)+I(r)+G+N X(Y)
$$

$Y=$ income,

$C(Y-T(Y))=$ consumption as a function of income, $Y$, and taxes, $T(Y)$,

$I(r)=$ investment as a decreasing function of the real interest rate, $r$,

$G=$ government spending,

$N X(Y)=$ net exports as a decreasing function of income, $Y$,

$$
Y=a Y(Y-T(Y))+\left[a Y-b\left(r-r^{\prime}\right)\right]+G+(X-I M)
$$

$r^{\prime}=$ marginal product of capital,

$X=$ exports,

$I M=$ imports,

The $L M$ relationship is,

$$
M / P=L(r, Y)
$$

Or, Money supply/Price level $=$ Liquidity Preference as a function of the real interest rate, $r$, and income, An increase in national income, $Y$, due to an increase in investment, decrease in the real interest rate, $r$, and increase in exports, $X$, may be achieved by differentiating Equation (19), assuming that government spending, $G$, is a constant, with respect to $I(r)$, and $X$,

$$
d Y / d X . d Y / d I(r)=a(-T(Y)))+\left[a-b\left(r-r^{\prime}\right)\right]+1-I M
$$

As an increase in national income increases business cash flow, the right side of Equation (22) may be substituted in the $L M$ relationship in Equation (21),

$$
M / P=a(-T(Y))+\left[a-b\left(r-r^{\prime}\right)\right]+(1-I M)
$$

Strong trade balances, (1-IM), low relative inflation, $P$, and low real interest rates, $r$, placed upward pressure on the Swiss franc, $S_{t}$.

According to Equation (1),

$$
\left(1+i_{s}\right)=E_{t}\left(S_{t+k}\right) / S_{t}\left(1+i_{c}\right)
$$

Rearranging Equation (1) to measure the future spot rate,

$$
E_{t}\left(S_{t+k}\right)=\left[-a(T(Y))+\left[a-b\left(r-r^{\prime}\right)\right]+(1-I M)\right]=\left(i+i_{s}\right) /\left(1+i_{c}\right) \cdot S_{t}
$$

The change in the expected future value of the Swiss franc suggests that $(1+$ $\left.i_{s}\right)$, the value of the Swiss franc, must increase over $\left(1+i_{c}\right)$, the value of the Euro, so that the right side of Equation (23) remains positive. The change in the Swiss 
franc is the first derivative of Equation (24),

$$
d\left(E_{t}\left(S_{t+k}\right) / d S_{t}\right)=[a-T(Y)]+\left[a-b\left(r-r^{\prime}\right)+(1-I M)\right]=\left(1+i_{s}\right) /\left(1+i_{c}\right)
$$

Despite numerous attempts by the Swiss National Bank to strengthen the Euro, with more purchases of Euros with Swiss francs, the underlying macroeconomic strengths of the Swiss economy prevailed. In January 2015, the peg was lifted, the EUR/CHF appreciating to the true value to $1.5545 E U R / 1 C H F$. In Figure 1, the peg shifts from point $O$ to point $P$.

Adjustable Rate Loan, 150 Basis Points above Three-Month LIBOR. A foreign currency mortgage borrower purchasing an adjustable rate mortgage expects an adjustment of interest rates approximately every six months. The lender loses if interest rates rise. Equation (26) shows the expectation of stable mortgage payments,

$$
=D C_{1}\left(1+r_{1}\right) e x_{1}+D C_{2}\left(1+r_{1}\right) e x_{1}+\ldots . D C_{n}\left(1+r_{1}\right) e x_{1}
$$

$D C_{1}=D C_{2} \ldots=D C_{n}=$ domestic currency to be converted to foreign curren$\mathrm{cy}$, to meet the monthly mortgage payment,

$r_{1}=$ the nominal interest rate $=150$ points + LIBOR, in periods 1 through $n$,

$e x_{1}=$ the exchange rate, in periods 1 through $n$.

The Taylor series expansion showing the variation of output, $x_{1}$, business investment as a function of the real interest rate, $x_{2}$, and the trade balance, $x_{3}$, about a point $(a, b)$,

$$
\begin{aligned}
& f(a, b)+\left(x_{1 t}-a\right) f_{x 1 t}(a, b)+\left(x_{2 t}-b\right) f x_{2 t}(a, b)+\left(x_{3 t}-b\right) f x_{3 t}(a, b) \\
& +1 / 2 !\left[\left(x_{1 t}-a\right)^{2} f x_{1 t} x_{2 t}(a, b)+2\left(x_{1 t}-a\right)\left(x_{2 t}-b\right) f x_{1 t} x_{2 t}(a, b)\right. \\
& \left.+\left(x_{2 t}-b\right)^{2} f x_{2 t} x_{2 t}(a, b)\right]+1 / 2 !\left[\left(x_{2 t}-a\right)\left(x_{2 t}-a\right) f x_{2 t} x_{2 t}(a, b)\right. \\
& \left.+2\left(x_{2 t}-a\right)\left(x_{3 t}-b\right) f x_{2 t} x_{3 t}(a, b)+\left(x_{3 t}-b\right)^{2} f x_{3 t} x_{3 t}(a, b)\right] \\
& +1 / 2 !\left[\left(x_{3 t}-a\right)^{2} f x_{1 t} x_{3 t}(a, b)+2\left(x_{3 t}-a\right)\left(x_{3 t}-b\right) f x_{1 t} x_{3 t}(a, b)\right. \\
& \left.+\left(x_{3 t}-b\right)^{2} f x_{3 t} x_{3 t}(a, b)\right]
\end{aligned}
$$

The first derivative of Equation (27) with negative values for change in output, $X_{1}$, change in investment, $x_{2}$, and change in trade, $x_{3}$, results in an exchange rate depreciation, $\left(1-i_{s}\right)>$ nominal interest rate differential, $\left(r-r^{2}\right)$, shows the depreciation in the exchange rate from reduction in output, reduction in investment, and a negative trade balance.

$$
\begin{aligned}
& f^{\prime}(a, b)+(-1-a) f_{x 1 t}^{\prime}(a, b)+(-1-b) f^{\prime} x_{2 t}(a, b)+(-1-b) f_{3 t}^{\prime}(a, b) \\
& +1 / 2 !\left[2 f^{\prime} x_{1 t} x_{2 t}(a, b)+2(-1-a)(-1-b) f^{\prime} x_{1 t} x_{2 t}(a, b)\right. \\
& \left.+2\left(x_{2 t}-b\right) f^{\prime} x_{2 t} x_{2 t}(a, b)\right]+1 / 2 !\left[2\left(x_{2 t}-a\right) f^{\prime} x_{2 t} x_{2 t}(a, b)\right. \\
& +2(-1-a)(1-b) f^{\prime} x_{2 t} x_{3 t}(a, b)+\left[2\left(x_{3 t}-b\right) f^{\prime} x_{3 t} x_{3 t}(a, b)\right] \\
& +1 / 2 !\left[2\left(x_{3 t}-a\right) f x_{1 t}^{\prime} x_{3 t}(a, b)+2(-1-a)(1-b) f^{\prime} x_{1 t} x_{3 t}(a, b)\right. \\
& \left.+2\left(x_{3 t}-b\right) f^{\prime} x_{3 t} x_{3 t}(a, b)\right]=d / d x\left(1-i_{s}\right) S_{t} /\left(1+i_{c}\right)
\end{aligned}
$$

An Interest-Only Mortgage with Balloon Payment. With an interest-only mortgage, each monthly payment consists of interest. No principal reduction occurs for the first 15-year period. The first 15-year period may be presented as follows, 


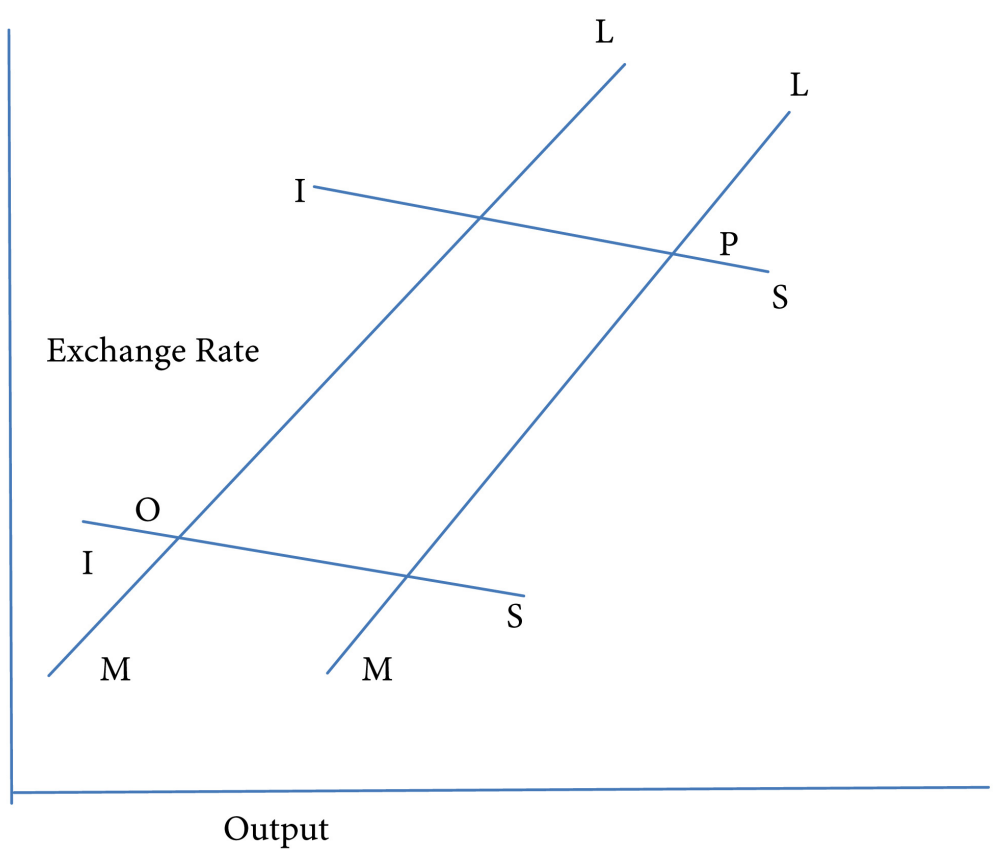

Figure 1. Pegged exchange rates and equilibrium exchange rates.

$$
\begin{aligned}
& D_{f}-D_{p}=\left(\text { Interest }_{1}\right) /\left(1+r_{1}\right)+\left(\text { Interest }_{2}\right) /\left(1+r_{2}\right)^{2} \\
& \left.+.\left(\text { Interest }_{15}\right) /\left(1+r_{15}\right)\right)^{15}+B A
\end{aligned}
$$

$D_{f}=$ Foreign Currency Value of Property,

$D_{V}=$ Foreign Currency Down Payment on Property,

$r=$ Interest rate on Mortgage,

$B A=$ Balloon Payment.

The mortgage is refinanced as the balloon payment becomes the new debt. The new mortgage becomes a foreign currency mortgage, with continuously rising monthly payments. The financing of the balloon payment is as follows,

$$
B A=P M T_{1} /\left(1+s_{1}\right)+P M T_{2} /\left(1+s_{2}\right)^{2}+. P M T_{n} /\left(1+s_{n}\right)^{n}
$$

This solution merely delays the onset of rising monthly payments.

A Repayment Vehicle into Which Monthly Payments Are Made. The Swiss banks successfully employed this measure with Austrian borrowers. Each borrower made monthly deposits into a liquid Euro account with sufficiently high returns to pay the higher monthly mortgage payments after Euro devaluation, the funds being invested in a high yielding corporate bond, whose interest stream was higher than the mortgage payments. This solution would be ineffective in Eastern Europe as the inflation and interest rate differentials are so high that severe domestic currency devaluation would result in such high monthly payments that the interest received from the corporate bond would be insufficient to meet monthly mortgage payments.

The repayment schedule for Austrian borrowers is shown in Equation (31),

$$
D_{f}-D P_{f}=D C_{1} e x_{1} /\left(1+s_{1}\right)+D C_{2} e x_{2} /\left(1+s_{2}\right)^{2}+D C_{3} /\left(1+s_{3}\right)^{3}
$$


The corporate bond has the income stream depicted in Equation (32),

$$
P V=\text { Interest }_{1}\left(1+s_{1}\right)+\text { Interest }_{2} /\left(1+s_{2}\right)^{2}+(\text { Par }+ \text { Interest })_{n} /\left(1+s_{n}\right)^{n}
$$

We impose the condition in Equation (33) that is met by Austrian borrowers,

$$
\begin{aligned}
& P V=\left(\text { Interest }_{1}-\text { DCex }_{1}\right) /\left(1+s_{1}\right)+\left(\text { Interest }_{2}-D C_{2} \text { ex }_{2}\right) /\left(1+s_{2}\right)^{2} \\
& +(\text { Par }+ \text { Interest })_{n} /\left(1+s_{n}\right)^{n}>0
\end{aligned}
$$

At the end of the bond's life, par + final interest payment will be sufficient to fully repay the mortgage. In contrast, in Eastern Europe, the exchange rate will decline to the extent that Interest $<D C e x$, so that a high-yielding corporate bond may be unable to meet rising monthly mortgage payments.

\section{The Proposed Solution for Emerging Market Borrowers}

This paper proposes that Eastern European borrowers reposition their mortgages as options on commodity futures. At time 0 , they must convert domestic currency into a foreign currency down payment, paid to the seller of residential property. From the first month onwards, for about 15 years, they pay a monthly mortgage payment to a foreign bank, exercising a call option to purchase a foreign currency futures contract. Initially, the foreign currency price is low, so the borrower exercises the option, obtains the futures contract, and purchases the foreign currency at an affordable price. Upon repeated devaluation, monthly payments continue to increase, so that the call buyer will be required to purchase options at progressively higher strike prices. This disincentivizes exercise of the call option. To encourage option exercise, a source of funds is created, that meets the cost of increasing strike prices. Each mortgage payment may be split into 2 parts. One portion may be allocated to current principal and interest payments, whereby conversion from domestic currency to foreign currency, occurs at the spot exchange rate. The remaining payment is allocated to the purchase of a series of 1-year futures contracts, paid from a high-return portfolio of oil, gold and silver, which have higher returns than the high-return equities portfolio of Section 3. The returns on this high-return portfolio pay the incremental increase in mortgage payments, thereby shielding borrowers from default.

Risk-Averse Purchasers of Foreign Currency. Borrowing using an increasing foreign currency mortgage is an aberration for the risk-averse borrower, who usually avoids default by selecting a fixed domestic currency mortgage. [38] modeled aberrant behavior as the third derivative of a Taylor series expansion. The line of aberrancy is a secant line which we present as tangent to the jump diffusion curve of prices of the foreign currency. [39] jump diffusion model is employed, with risky options on foreign currency prices varying sharply in jumps from 1 period to the next. The point of tangency in Figure 2 of the line of aberrancy with the jump-diffusion curve depicts the rate of reduction in satisfaction in purchasing the foreign currency mortgage due to depreciation of the exchange rate. Equating the utility of satisfaction from investing in a call option on 


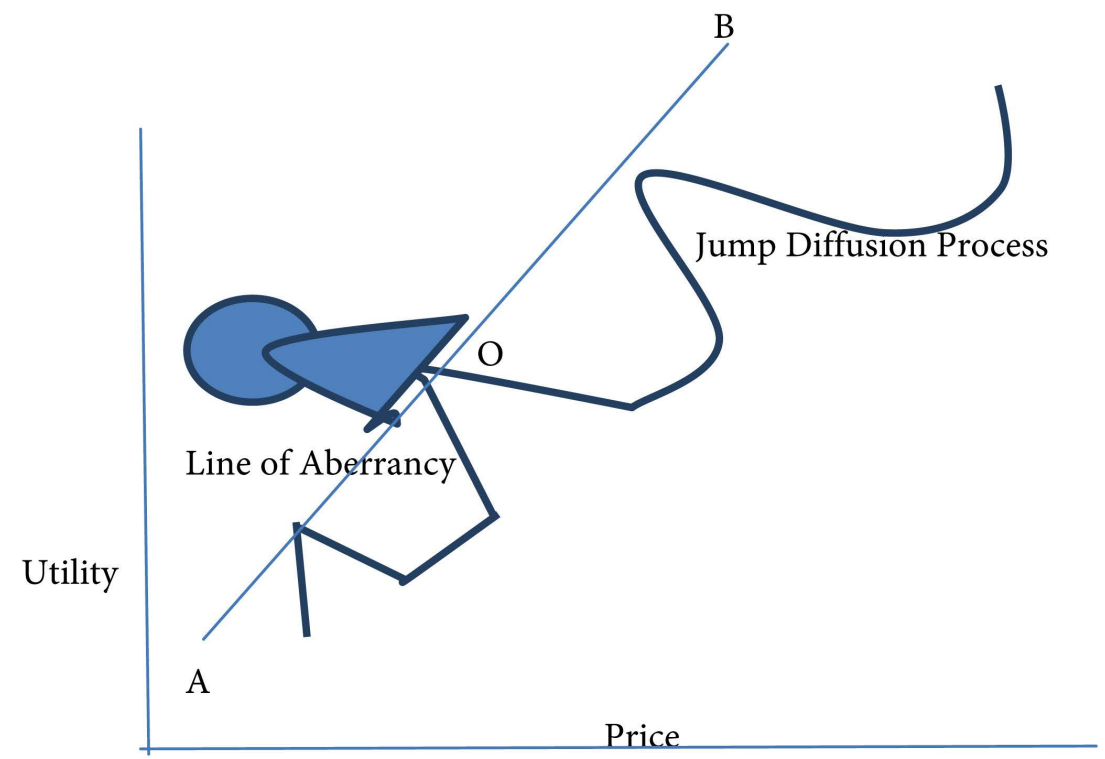

Figure 2. Optimal price for the risk-averse borrower of foreign currency.

currency futures, with [39]'s jump diffusion model, yields the spot price of options on currency futures in Equation (35). The secant line for expected returns from call options on currency futures is the line of aberrancy, defined as,

$$
x_{t}=s-\left(1 / 6 \rho^{2}\right)\left(s^{3}\right)+\left[\rho(\text { mean }) / 8 \rho^{4}\right]\left(s^{4}\right)+\ldots . .
$$

$y_{t}=$ Utility of satisfaction from investing in a call option on currency futures,

$1 /(2 \rho) s^{2} \rho / 6 \rho^{2}\left(s^{3}\right)-\left[\rho^{2}-3 \rho(\text { mean })^{2} / 24 \rho^{5}+\rho(\right.$ mean $\left.)\right] s s s s$

$=$ Spot price of an option on futures $\left.* \exp \left[\alpha-1 / 2 \sigma^{2}-\lambda k\right) t+\sigma Z(t)\right] Y(n)$

$s=$ arc length of the secant line,

$\rho=$ radius of curvature of line of aberrancy,

$\alpha=$ mean,

$\sigma^{2}=$ variance of emerging market currency underlying the futures contract,

k $=$ constants,

$Z(t)=$ Gaussian random variable,

$Y(n)=$ Poisson random variable.

Spot price of option on currency futures

$$
\begin{aligned}
& =1 / \exp \left[\left(\alpha-1 / 2 \sigma^{2}-\lambda k\right) t+\sigma Z(t)\right] Y(n)[1 /(2 \rho) s s-\rho / 6 \rho \rho(s s s) \\
& -\left[\rho \rho-3 \rho(\text { mean })^{2} / 24 \rho^{5}+\rho(\text { mean })\right] \text { sss }
\end{aligned}
$$

The futures price of options on currency futures is the combination of call option prices on 1-period futures contracts with successively higher prices. The total value of all options on futures contracts during the delivery period is obtained by integrating Equation (36).

$$
\begin{aligned}
& \int\left[1 / \exp \left[\alpha+1 / 2 \sigma^{2}-\lambda k\right) t+\sigma Z(t)\right] Y(n)\left[1 / 2 \rho s^{2}-\rho / 6 \rho^{2}\left(s^{3}\right)\right. \\
& \left.-\left[\rho^{2}-3 \rho(\text { mean })\right] / 24 \rho^{5}+\rho(\text { mean })\right] \text { ssss }
\end{aligned}
$$

The upper bound, or maximum spot and futures call price, occurs at $\eta \dot{\eta}$, 


$$
\begin{gathered}
d / d x \lim \dot{\eta} \rightarrow 1\left[c^{1-\tilde{\eta}} /(1-\dot{\eta})\right]=\ln (c) \\
\left.d^{2} x / d x^{2}=0=1 / c=\exp \left[\alpha-0.5 \sigma^{2}-\lambda k\right) t+\sigma Z(t)\right] Y(n)
\end{gathered}
$$

A risk-averse call buyer purchases the option on Eastern European currency futures. The option is highly volatile, its premium varying intraday, by the hour. We assume that options are priced on futures contracts that arrive by the nanosecond in [39]'s formulation,

$$
=\left(\alpha_{W}-\lambda k_{W}\right) d t+\sigma_{W} d Z+d q_{W}
$$

$\left(\alpha_{w}-k_{w}\right)=$ mean option prices,

$\sigma_{w}=$ standard deviation of option prices,

$d q=$ random variable Poisson process.

Figure 2 depicts the optimal foreign currency price for the risk-averse borrower at point $O$, the intersection of the line of aberrancy and the apex of a jump on the jump diffusion curve.

Alternatively, this pricing distribution may be represented as a martingale process. The martingale process assumes that the conditional expectation of the next value is independent of historical values [40]. As option prices are completely unpredictable from past prices [41], we may approximate the option price distribution to de Moivre's martingale, with the probability, $p$, of exchange rate depreciation, and $q=1-p$, of unchanged exchange rates.

Let $X_{n+1}=X_{n}+/-1$, where $+=$ depreciated exchange rates, and $-=$ unchanged exchange rates. Let $Y_{n}=(q / p) X_{n}$. Then, $\left\{Y_{n}: n=1,2,3 \ldots\right\}$ is a martingale with respect to $\left\{X_{n}: n=1,2,3 \ldots\right\}$

$$
E\left[Y_{n+1} \mid X_{1} \ldots X_{n}\right]=p\left(q \cdot p^{-1}\right) \exp X_{n+1}+q\left(q p^{-1}\right) \exp X_{n-1}
$$

The right side of Equation (41) is equal to,

$$
q \cdot(q p)^{-1} \exp X_{n-1}+p(q p)^{-1} \exp X_{n+1}
$$

The value of the call option $=$ option on futures contract at the spot price + option on futures contract at futures price for a martingale, OR, The value of the call option $=$ option on futures contract at spot price + option on futures contract at futures price for a jump diffusion process,

$$
\begin{aligned}
& \text { price of option } p \cdot(q p)^{-1} \exp X_{n+1}+q(q p)^{-1} \exp X_{n-1}+\text { Equation (36) } \\
& =\text { price of option }\left(\alpha_{w}-\lambda k_{w}\right) d t+\sigma_{w} d Z+d q_{w}+\text { Equation (36) }
\end{aligned}
$$

As $p$, the probability of exchange rate depreciation, continues to increase in each period, the borrower must invest in a high return portfolio of oil, gold, and platinum 1-year maturity commodity futures contracts. Returns on these investments will be sufficiently high to meet the mortgage payment even with rising monthly payments.

The shape of the oil price distribution in Figure 3, derived from actual oil price charts from 2010-2015 [41], conforms to a gamma distribution. The cumulative density function of a gamma distribution is defined by a shape parameter, $k$, and a scale parameter, $\theta$. For values of $k=0.5-7.5$, and $\theta=0.5-2.0$, 


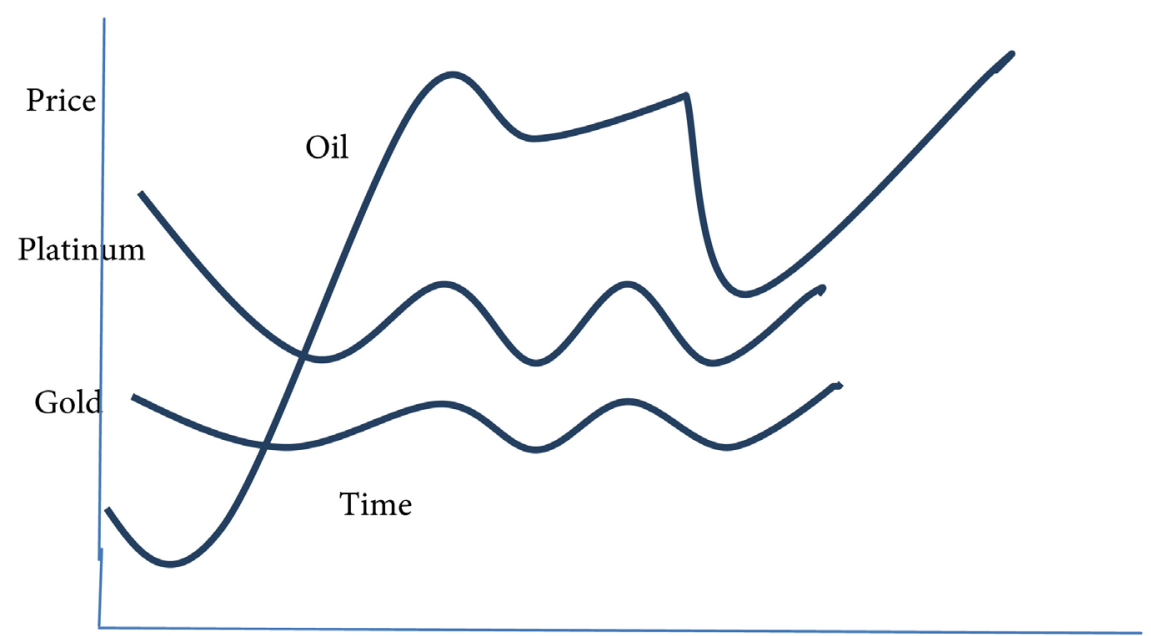

Figure 3. Historic price distributions OfOil, platinum, and gold.

the gamma distribution has a shape that is similar to that of historical oil prices, as shown in Figure 3 [42]. We may express the price function as the product of price and an asymptotic function of the gamma distribution, as shown in Equation (43).

$$
\begin{gathered}
\Gamma(a z+b)=\text { Price } \sqrt{2 \Pi e^{-a z}(a z)^{a z}}+\partial-0.5|\arg z|<\Pi, a>0 \\
\ln \Gamma(z)=(z-0.5) \ln z-z+0.5 \ln (2 \Pi)+\sum B_{2 m} /\left(2 m(m-1) z^{2 m-1}\right.
\end{gathered}
$$

Equation (43) includes a Bernoulli function $B_{2 m}$, which envisions two states, i.e. oil price increases with value $=0$, and oil price decreases with value $=1$. Similar states exist for gold and platinum. The maximum of the oil price distribution is obtained by twice differentiating Equation (43). The first derivative of Equation (43) with respect to $z$ is listed in Equation (44),

$$
\begin{aligned}
& =\text { Price } \Pi e^{-a z} a(a z)<\Pi, a>0 \\
& 1 / \Gamma(z)=(1-0.5) / z-1+B_{2 m} / 2 m(m-1)(2 m-1) z
\end{aligned}
$$

Substituting for the change in the Bernoulli function,

$$
1 / \Gamma(z)=(1-0.5) / z-1+n x^{n-1} / 2 m(m-1)(2 m-1) z
$$

The second derivative of Equation (43) with respect to $z$, equated to 0 , is listed in Equation (46),

$$
1 / \Gamma^{\prime}(z)=0.5+n x^{n-1} / 2 m(m-1)(2 m-1)=0
$$

Equation (46) represents the maximum value of the foreign currency. Upon reaching the maximum, a Fourier expansion may be used to depict the boundary of the Bernoulli function, signaling a change in direction of oil, gold, or platinum to a forthcoming decrease in value. The Fourier expansion is presented as follows [34],

$$
\begin{gathered}
B_{n}(x)=-2 n ! /(2 \Pi)^{n} \sum \cos (2 \Pi k x-0.5 \Pi n) / k^{n}(k=1 \text { to } \infty) \\
n>1,1 \geq x \geq 0 ; n=1,1>x>0
\end{gathered}
$$


Decreases in commodity returns act as a signal to the foreign currency borrower to sell the commodity future, use part of the proceeds to pay the mortgage payment, and then, purchase a futures contract on another commodity, like copper, with increasing future value. Figure 3 shows that gold or platinum have different price distributions from oil. The continuous wave distribution may be likened to a Bessel function, [43], We employ Bessel functions, to which we add dichotomous Bernoulli functions to account for price increases and price decreases, to describe gold or platinum price distributions in Equation (48) [44],

$$
\begin{aligned}
& Y_{n}=(0.5 z)^{-n} / \Pi \sum(n-k-1) ! / k !\left(0.25 z^{2}\right)^{k}+2 / \Pi \ln (0.5 z)\left(J_{n}(z)-(0.5 z)^{n} / \Pi\right. \\
& \left.\left.\sum \phi(k+1)+\phi(n+k+1)\right)-0.25 z^{\wedge} 2\right)^{\wedge} k / k !(n+k) !+B_{2 n}
\end{aligned}
$$

where,

$$
\begin{gathered}
J(z)=(0.5 z)^{y} \sum\left(-0.25 z^{2}\right)^{k} / k ! \Gamma(v+k+1) \\
\phi=-^{\prime} \Upsilon_{1} \phi(n)=-^{\prime} \Upsilon+\sum k 1 \text { ton }-1 k^{-1}(n \geq 2)
\end{gathered}
$$

The sell signal for gold and platinum is followed by purchase of a futures contract, whose projected forward prices show increases, such as copper.

\subsection{Risk-Taker Purchasers of Foreign Currency}

Risk-takers gain satisfaction from taking risk. [45] describes such utility as risk-causing. [46] described such individuals as deriving utility from the perception that the gambling behavior could yield significant enough rewards to uplift them to higher socioeconomic status. He theorized that risk-takers have high initial risk, and high optimal levels of risk, indicating that they are risk-takers from the outset, with acceptance of high levels of subsequent risk. [47] concurred with his empirical finding that such individuals would take unfair bets. Given that the foreign currency mortgage is a highly risky liability, risk-takers accept it initially, regardless of consideration of risk. They continue to purchase foreign currency, long after depreciation of the domestic currency, as they are not adversely affected by increased risk from continuously appreciating foreign currency values. Their utility function may be modeled by Wronskian relations with rapid acceptance of higher foreign currency values in the $G_{L}$ segment of the utility function depicted in Figure 4. Prices at intersection of the Wronskian function with the jump process yield optimal conversion prices. The Wronskian utility function may be modeled as [34].

$$
\begin{aligned}
& \text { If } u_{L}=F_{L}(\dot{\eta} \rho) \text { or } G_{L}(\dot{\eta} \rho) \\
& \qquad \frac{L d u_{L}}{d p}=\left(L^{2}+\dot{\eta}^{2}\right)^{0.5} u_{L-1}-\left(\frac{L^{2}}{\rho}+\dot{\eta}\right) u_{L}
\end{aligned}
$$

Equating the second derivative of the Wronskian utility function with the jump process weighted by price yields the formulation of the price of foreign currency, $P^{\star}$, for the risk-taking borrower,

$$
\frac{L d_{u L}^{2}}{d p^{2}}=\frac{\left(L^{2}+\dot{\eta}^{2}\right) d u_{L-1}}{d t}-\frac{\left(L^{2} \rho^{-2}+\dot{\eta}\right) d u_{L}}{d t}=P\left(\alpha_{w}-\lambda k_{w}\right) d t+\sigma_{w} d Z+d q_{w}
$$




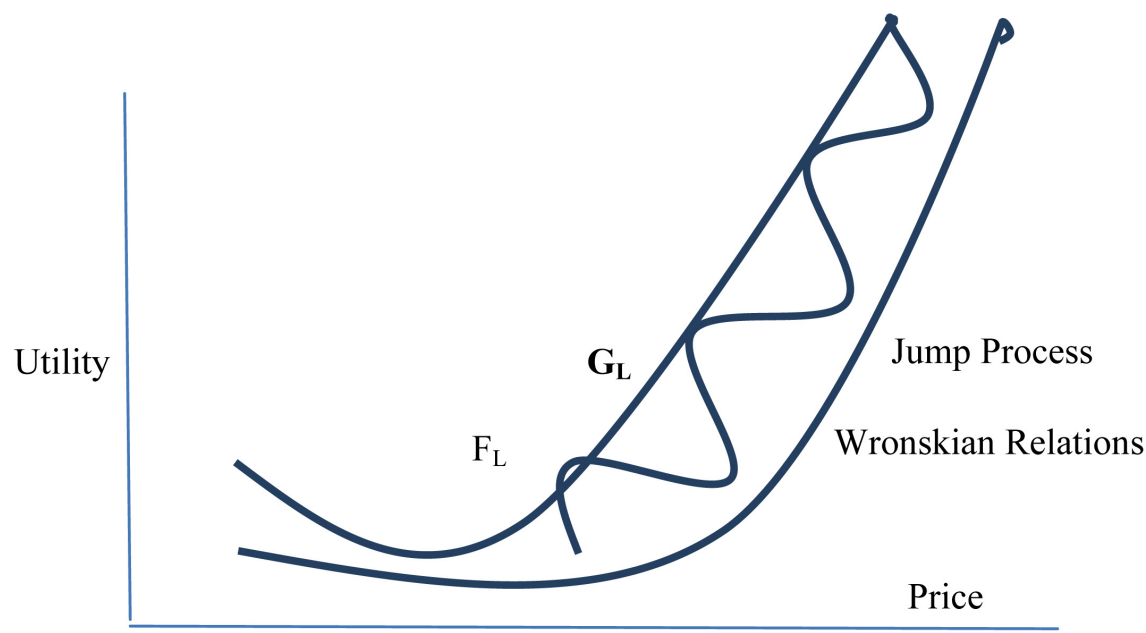

Figure 4. Optimal price paid by risk-takers to purchase foreign currency.

\subsection{An Alternative Solution to Preserve Foreign Currency Values with Default of Principal}

Another solution would be to short the domestic currency as it depreciates. The proceeds may be sufficient to offset the loss from default of the foreign currency mortgage, until the loan is sold to a domestic lender.

Risk-Averse Investor. The proceeds from the short sale may be presented as the intersection of a risk-averse investor's utility function with the product of short sale gain and the price distribution of the domestic currency as a Legendre function. The first constraint establishes that the domestic currency, $x$, depreciates in value from time periods 1 through $n$. The second constraint equates the price distribution of the principal of the mortgage to 0 , or establishes that the mortgage is in default.

If $y_{t}=$ the utility of satisfaction from investing in currency that is expected to depreciate,

$s=$ arc length of a secant line,

$\rho=$ radius of curvature of the line of aberrancy,

$D=$ principal of mortgage in default

Max

$$
\begin{aligned}
& 1 /(2 \rho) s^{2} \rho\left(6 \rho^{2}\left(s^{3}\right)-\left[\rho^{2}-\frac{3 \rho(\text { mean })^{2}}{24 \rho^{5}}+\rho(\text { mean }) s^{4}\right.\right. \\
& -(\text { Selling price - Purchase price })\left\{\frac{\left[\frac{1}{\Pi \int x_{t} x_{t}^{2}}-1\right)^{0.5}(2 t-1)^{s} d t}{t^{5}(1-t)}\right] \\
& +\left[1 / \Pi \int x\left(x^{2}-1\right)^{0.5}(2 t-1)^{s} d t / t(t-1)^{0.5}\right]
\end{aligned}
$$

Subject to,

$$
\begin{gathered}
x_{n}<\ldots x_{3}<x_{2}<x_{1} /(1+r)^{n} \\
D *(a+b x)=0
\end{gathered}
$$




$$
\begin{aligned}
& 1 /(2 \rho) s^{2} \rho\left(6 \rho^{2}\left(s^{3}\right)-\left[\rho^{2}-\frac{3 \rho(\text { mean })^{2}}{24 \rho^{5}}+\rho(\text { mean }) s^{4}\right.\right. \\
& -(\text { Selling price }- \text { Purchase price })\left\{\frac{\left[\frac{1}{\Pi \int x_{t} x_{t}^{2}}-1\right)^{0.5}(2 t-1)^{s} d t}{t^{5}(1-t)}\right] \\
& +\left[1 / \Pi \int x\left(x^{2}-1\right)^{0.5}(2 t-1)^{s} d t / t(t-1)^{.5}\right]-L_{1}\left(x_{n}-\frac{x_{1}}{(1+r)^{n}}-L_{2} D(a+b x)\right.
\end{aligned}
$$

The necessary condition for optimization is the first derivative of Equation (53),

$$
\begin{aligned}
& 3 s^{3} / \rho-\left[2 \rho-\frac{3(\text { mean })^{2}}{120 \rho^{4}}+3(\text { mean }) s^{3}\right. \\
& -(\text { Selling price }- \text { Purchase price })\left\{\frac{\left.1-\frac{1}{2 \Pi x_{t}}\right)^{0.5}(2 t-1)^{s} d t}{t^{5}(1-t)}\right] \\
& +\left[1 / \Pi x\left(x^{2}-1\right)^{0.5} s(2 t-1)^{s-1} d^{2} t / t(t-1)^{0.5}\right]-L_{1}\left(1-\frac{1}{(1+r)^{n}}-L_{2} D(b)\right.
\end{aligned}
$$

The sufficient condition for optimization is the second derivative of Equation $(53)=0$,

$$
\begin{aligned}
& 6 s-\left[2-\frac{3(\text { mean })^{2}}{480 \rho^{3}}+9(\text { mean }) s^{2}-(\text { Selling price }- \text { Purchase price })\right. \\
& \left.\left\{\frac{\left[\frac{1}{2 \Pi}\right)^{0.5}(2 t-1)^{s} d t}{t^{0.5}(1-t)}\right]+\frac{1}{\Pi(2 x)^{0.5}(2 t-1)^{s}}-1 d^{3} t / t(t-1)^{0.5}\right] \\
& -L_{1}\left[-\frac{1}{(1+r)^{n}}-L_{2} D b\right]=0
\end{aligned}
$$

The Risk-Taker. The utility function of the risk-taker may be modeled by Wronskian relations with rapid acceptance of higher foreign currency values in the $G_{L}$ segment. Short sale gains of Selling Price - Purchase Price taken at the intersection of the Wronskian utility function with the Legendre price function to yield optimal short sale gains upon default of the foreign currency mortgage. The Wronskian utility function may be modeled as [34],

$$
\begin{aligned}
& \text { If } u_{L}=F_{L}(\dot{\eta} \rho) \text { or } G_{L}(\dot{\eta} \rho) \\
& \qquad \frac{L d u_{L}}{d p}=\left(L^{2}+\dot{\eta}^{2}\right)^{0.5} u_{L-1}-\left(\frac{L^{2}}{\rho}+\dot{\eta}\right) u_{L}
\end{aligned}
$$

Equating the second derivative of the utility function with the right side of Equation (70), yields the short sale gain for the risk-taking borrower,

$$
\begin{aligned}
& \frac{L d_{u L}^{2}}{d p^{2}}=\frac{\left(L^{2}+\dot{\eta}^{2}\right) d u_{L-1}}{d t}-\frac{\left(L^{2} \rho^{-2}+\eta ́ \eta\right) d u_{L}}{d t}-(\text { Selling price }- \text { Purchase price }) \\
& \left.\left\{\frac{\left[\frac{1}{2 \Pi}\right)^{0.5}(2 t-1)^{s} d t}{t^{.5}(1-t)}\right]+\frac{1}{\Pi(2 x)^{0.5}(2 t-1)^{s}}-1 d^{3} t / t(t-1)^{0.5}\right] \\
& -L_{1}\left[-\frac{1}{(1+r)^{n}}-L_{2} D b\right]=0
\end{aligned}
$$




\section{Conclusions}

This paper has theoretically explored the problem of defaults of foreign currency mortgages. Existing solutions have largely been found to offer temporary relief to buyers confronting increasing monthly payments. By recasting the repayment process as a commodity purchase, and by offering an investment portfolio that caters to both to borrowers who are modestly impacted by foreign currency devaluations, and those who are significantly affected by foreign currency devaluations, this paper has sought to offer a solution that benefits both lender and borrower. This paper perceives borrowers as varying in risk aversion, yielding two sets of solutions as each utility function intersects with the price distribution. The theoretical basis for the interest rate differential between the two economies, lies in uncovered interest parity.

The primary implication of this paper for banking is that the proposed solution is suboptimal, in that it does not ameliorate the underlying macroeconomic weaknesses that lead to the interest rate differentials that cause domestic currency depreciation, and in turn, increase monthly mortgage payments. Central banks should curb frequent depreciation by aiming for low, stable real interest rates of about $2 \%-4 \%$, followed by controlling inflation, reducing the budget deficit, and reducing the trade deficit to achieve long-term macroeconomic, and exchange rate stability.

The alternative solution of shorting the domestic currency to offset defaults of foreign currency mortgages raises research questions that must be explored in future work. The short selling strategy would be more effective, provided that management is willing to accept the borrowing costs. Why has this strategy not been used extensively? It is possible that the dichotomy between the foreign currency market in which currencies are traded and banks which supply mortgages is absolute for risk-averse traders, so that traders in the foreign currency market rarely interact with bankers who originate mortgages. It would not occur to certain bankers that a problem in banking could be solved through trading in the financial markets.

\section{Conflicts of Interest}

The authors declare no conflicts of interest regarding the publication of this paper.

\section{References}

[1] Directorate General for Internal Policies (2018) Mis-Selling if Financial Products: Mortgage Credit. Policy Department A: Economic and Scientific Policy. IP/A/Econ/2016-17, PE 618.995.

[2] Albacete, N., and Lindner, P. (2015) Foreign Currency Borrowers in Austria-Evidence from the Household Finance and Consumption Survey. Financial Stability Report, 29, 93-109.

[3] Feenstra, R.C. and Taylor, A.M. (2008) International Macroeconomics. Worth Publications, New York. 
[4] Dornbusch, R. (1976) Expectations and Exchange Rate Dynamics. Journal of Political Economy, 8, 1161-1176. https://doi.org/10.1086/260506

[5] Fama, E.F. (1984) Forward and Spot Exchange Rates. Journal of Monetary Economics, 14, 319-338. https://doi.org/10.1016/0304-3932(84)90046-1

[6] Ito, T. and Roley, V.V. (1986) News From The U.S. and Japan: Which Moves the Yen/Dollar Exchange Rate? NBER Working Paper No. 1853. Monetary Economics, NBER Program. https://doi.org/10.3386/w1853

[7] Abuaf, N. and Jorion, P. (1990) Purchasing Power Parity in the Long Run. The Journal of Finance, 45, 157-174. https://doi.org/10.1111/j.1540-6261.1990.tb05085.x

[8] Ocal, O. (2013) Purchasing Power Parity in the Cajse of Romania: Evidence from Structural Breaks. International Journal of Economics and Financial Issues, 3, 973-976.

[9] Christev, A. and Noorbaksh, A. (2000) Long-Run Purchasing Power Parity, Price and Exchange Rate in Transition: The Case of Six Central and East European Countries. Global Finance Journal, 11, 87-108.

https://doi.org/10.1016/S1044-0283(00)00016-8

[10] Barlow, D. (2003) Purchasing Power Parity in Three Transition Economies. Economics of Planning, 36, 201-221.

https://doi.org/10.1023/B:ECOP.0000024027.98358.4f

[11] Sideris, D. (2006) Purchasing Power Parity in Economies in Transition: Evidence from Central and East European Countries. Applied Financial Economies, 16, 135-143. https://doi.org/10.1080/09603100500390141

[12] Koukouritakis, M. (2006) Testing the Purchasing Power Parity: Evidence from the New EU Countries. Applied Economics Letters, 16, 39-44. https://doi.org/10.1080/13504850701735807

[13] Cuestas, J. C. (2009) Purchasing Power Parity in Central and Eastern European Countries: An Analysis of Unit Root and Nonlinearities. Applied Economics Letters, 16, 87-94. https://doi.org/10.1080/13504850802112252

[14] Acaravci, A. and Ozturk, A. (2010) Testing Purchasing Power Parity in Transition Countries: Evidence from Structural Breaks. The AMFITEATRU ECONOMIC Journal, 12, 190-198.

[15] Chang, H.-L., Su, C.-W., Zhu, M.-N. and Liu, P. (2011) Re-Examining Long Run Purchasing Power Parity for Central and Eastern European Countries: Nonlinear Panel Root Tests. Applied Economics Letters, 18, 411-415. https://doi.org/10.1080/13504851003724218

[16] Twarowski, K. and Kakol, M. (2014) Analysis of Factors Influencing Fluctuations in the Exchange Rate of the Polish Zloty Against Euro. Management Learning and International Conference Proceedings, Slovenia, 25-27 June 2014, 889-898.

[17] Kriljenko, C. and Habermeir, K. (2004) Structural Factors Affecting Exchange Rate Volatility: A Cross Section Study. International Monetary Fund, Washington DC.

[18] Kravis, I.B. and Lipsey, R.E. (1991) The International Comparison Program: Current Status and Problems. In: Harper, P. and Richardson, J.D., Eds., International Economic Transactions. Issues in Measurement and Empirical Research, National Bureau of Economic Research Studies in Income and Wealth, University of Chicago Press, Chicago, IL. https://doi.org/10.3386/w3304

[19] Taylor, M.P. and Kim, H. (2008) Real Variables, Nonlinearity and European Real Exchange Rates. NBER International Seminar on Macroeconomics, 5, 157-193. https://doi.org/10.1086/596004 
[20] Branson, W.H., Haltunen, H. and Masson, P.R. (1977) Exchange Rate in the Short Run. European Economic Review, 10, 303-324. https://doi.org/10.1016/S0014-2921(77)80002-0

[21] Kama-Ainur, A. and Condrea, C. (2002) Some Empirical Evidence About the Effects of Macroeconomic Variables on the Exchange Rate in Romania. Transformations in Business \& Economics, 11, 435-450.

[22] Rosenberg, C. and Tirpak, M. (2009) Determinants of Foreign Currency Borrowing in the New Member States of the EU. Czech Journal of Economics and Finance, 59, 216-228.

[23] Ize, A. and Yeyati, E.L. (2003) Financial Dollarization. Journal of International Economics, 59, 323-347. https://doi.org/10.1016/S0022-1996(02)00017-X

[24] Kiraly, J. and Simonovits, A. (2015) Mortgages Denominated In Domestic and Foreign Currencies: Simple Models. Institute of Economics, Centre for Economic and Regional Studies, Hungarian Academy of Sciences, Budapest.

[25] Beer, C., Ongena, S. and Peter, M. (2008) Borrowing in Foreign Currency: Austrian Households as Carry Traders. Swiss National Bank Working Paper Series.

[26] Hassan, S., and Simione, F. (2010) Exchange Rate Determination under Monetary Policy Rules in a Financially Underdeveloped Economy: A Simple Model and Application to Mozambique. Working Paper 192, University of Cape Town, Cape Town.

[27] Lyons, R.K. and Rose, A.K. (1995) Explaining Forward Exchange Bias...Intraday. The Journal of Finance, 50, 1321-1329.

[28] Chaboud, A.P. and Wright, J.H. (2003) Uncovered Interest Parity: It Works, but Not for Long. International Finance Discussion Papers, Board of Governors, Federal Reserve System, No. 752t. https://doi.org/10.17016/IFDP.2003.752r

[29] Bjornland, H.C. (2009) Monetary Policy and Exchange Rate Overshooting: Dornbusch Was Right after All. Journal of International Economics, 79, 64-77. https://doi.org/10.1016/j.jinteco.2009.06.003

[30] Black, F. (1976) The Pricing of Commodity Contracts. Journal of Financial Economics, 3, 167-179. https://doi.org/10.1016/0304-405X(76)90024-6

[31] Milterson, K.R. and Schwartz, E.S. (1998) Pricing Options on Commodity Futures with Stochastic Term Structure Yields and Interest Rates. The Journal of Financial and Quantitative Analysis, 33, 33-59. https://doi.org/10.2307/2331377

[32] Hilliard, J.E. and Reis, J. (1998) Valuation of Commodity Futures and Options under Stochastic Convenience Yields, Interest Rates, and Jump Diffusions in the Spot. The Journal of Financial and Quantitative Analysis, 33, 61-86. https://doi.org/10.2307/2331378

[33] Mirantes, A.G., Poblacion, J. and Serna, G. (2015) Commodity Derivative Valuation under a Factor Model with Time-Varying Market Prices of Risk. Review of Derivatives Research, 18, 75-93. https://doi.org/10.1007/s11147-014-9104-1

[34] Abramowitz, M. and Stegun, I. (1964) Handbook of Mathematical Functions with Formulas, Graphs, and Mathematical Tables (National Bureau of Economic Research-Applied Mathematics Series No. 55). Journal of Applied Mechanics, 32, 239. https://doi.org/10.1115/1.3625776

[35] Norton, R.E. (1984) The Double Exponential Distribution: Using Calculus To Find a Maximum Likelihood Estimator. The American Statistician, 38, 135-136. https://doi.org/10.2307/2683252

[36] Admiral Markets (2017) Price Shock: When the Swiss National Bank Unpegged the 
Swiss Franc from the Euro. https://admiralmarkets.com/about-us/contact-us

[37] Gordon, R.J. (2009) Macroeconomics. 11th Edition, Pearson, Boston, MA.

[38] Schot, S. (1978) Aberrancy: Geometry of the Third Derivative. Mathematics Magazine, 51, 259-275. https://doi.org/10.1080/0025570X.1978.11976728

[39] Merton, R.C. (1975) Option Pricing When Underlying Stock Returns Are Discontinuous. Working Paper WP 787-75. Massachusetts Institute of Technology, Cambridge, MA.

[40] Williams, D. (1991) Probability with Martingales. Cambridge University Press, Cambridge. https://doi.org/10.1017/CBO9780511813658

[41] Macrotrends (2018) Crude Oil Prices-70 Year Historical Chart. https://www.macrotrends.net/1369/crude-oil-price-history-chart

[42] Park, S.Y. and Bera, A.K. (2009) Maximum Entropy Autoregressive Conditional Heteroskedasticity Model. Journal of Econometrics, 12, 219-230. https://doi.org/10.1016/j.jeconom.2008.12.014

[43] Watson, G.N. (1995) A Treatise on the Theory of Bessel Functions. Cambridge University Press, Cambridge.

[44] Minka, T. (2000) Beyond Newton's Method. https://research.microsoft.com/"minka/papers/newto.html

[45] Zou, B. (2011) The Utility of Uncertainty: Using Gambling Behavior to Understand Individual Preferences under Background Risk. Unpublished Master's Thesis, Northwestern University, Evanston, IL.

[46] Friedman, M. and Savage, L.J. (1948) The Utility Analysis of Choices Involving Risk. The Journal of Political Economy, 56, 279-304. https://doi.org/10.1086/256692

[47] Brunk, G.G. (1981) A Test of the Friedman-Savage Gambling Model. The Quarterly Journal of Economics, 96, 341-348. https://doi.org/10.2307/1882394 